\title{
Impact of Liquidity on the Profitability of the Commercial Banks of Nepal
}

\author{
Churamani Pandey \\ Lecturer, Nepal Commerce Campus, T.U. \\ Rupesh Kumar Budhathoki
}

\begin{abstract}
The study aims to examine the impact of liquidity on the profitability of Nepalese commercial banks. Investment ratio, capital ratio and liquidity ratio are the independent variables and return on assets is dependent variable. Secondary sources of data have been used from the annual reports of sampled commercial banks. The regression models are estimated to test the effect of bank liquidity on performance of Nepalese commercial banks. Study results reveal that investment ratios and liquidity ratios are negatively related to return on assets indicating that higher the investment ratios and liquidity ratios, lower would be the return on assets and vice versa. Further, the relationship between capital ratios and return on assets is found to be positive indicating that higher the capital ratios of the bank, higher would be the return on assets. Similarly, beta coefficient for capital ratio is positively significant with bank performance, which indicates that increase in capital ratio leads to increase the performance of the banks. However, beta coefficients for investment ratio and liquidity ratio are negative with return on assets indicating increased liquidity ratio and investment ratio decrease the return on assets of the bank.
\end{abstract}

Keywords: Investment ratio, Capital ratio, Liquidity ratio, Return on assets, Return on equity

\section{Introduction}

The liquidity of an organization is considered as most important component for it to pay its current liabilities. It includes payment of obligation and the other financial expenses which are considered as short term. There is an inverse relationship between profitability and liquidity ratio. If we want to increase profitability then we have to sacrifice liquidity. At the same time, increased liquidity will be on the cost of profitability.

The liquidity in the commercial bank represents the ability to fund its obligations by the party at the time of maturity, which includes lending and investment commitments, withdrawals, deposits, and accrued liabilities (Amengor, 2010).

Liquidity and profitability has got tremendous importance in the corporate world. Liquidity refers to the management of current assets and current liabilities of a company. It plays key role in defining, whether a firm is able to effectively manage its short-term obligations. Due to its critical importance, it is important for firms to maintain a reasonable amount of assets in the form of cash in order to meet their short-term obligations. Balanced liquidity level is necessary for the effectiveness and profitability of a firm. Therefore, 
firms need to determine the optimum level of the liquidity in order to ensure high profitability. Liquidity, should neither be too low nor too high. Rather, it should maintain a reasonable level. Whereas, profitability refers to the revenues earned by firms, against their operations and incurred expenses. In order to find the profitability level of firms, profitability ratios are used, whereby it can clearly be examined where the firm stands in terms of profitability. Enhancement of profitability is the ultimate purpose of every firm, and each of them attempts to achieve optimum profitability. Since, there is a significant relationship between liquidity and profitability of the firm, so the firm is required to maintain optimum level of liquidity (Khan \& Ali, 2016).

Sunny (2013) states that a firm should ensure that it does not suffer from lack-of or excess liquidity to meet its short-term compulsions. A study of liquidity is of major importance to both the internal and the external analysts because of its close relationship with day-to-day operations of a business. On the other hand, Nahum and Amarjit (2013) clarify that dilemma in liquidity management is to achieve desired tradeoff between liquidity and profitability.

Banking sector plays a vital role in the economic growth and development of Nepal. The importance of an efficient banking sector lies in the fact that it ensures generation and mobilization of savings, and investments in productive sectors. In fact, this system assists in directing most profitable and efficient sectors to most productive sources of future growth. Banking being an important sector of financial system of Nepal, the study on performance of banking sector and evaluation of determinants of profitability remain as a prudent area of research on financial system. Therefore, this study aims to examine how liquidity impacts the profitability of some selected banks of Nepal in order to provide insight for improving banks' profitability through better asset and liability management of banks in Nepal.

\section{Literature review}

Malik et al. (2016) conducted a research work to inspect the trade-off between liquidity and profitability in private sector banks of Pakistan. The study was carried on twenty two private sector banks registered under State bank of Pakistan during the time period of 2009-2013. Three models were specified and estimated using Ordinary Least Squares (OLS) technique. The empirical results revealed that there is a statistically significant relationship between bank liquidity measures and return on assets. However, when return on equity and return on investment was used as proxy for profitability, the relationship became statistically insignificant.

Abdullah and Jahan (2014) attempted to investigate the impact of liquidity and profitability of the private commercial banks of CSE-30 in Bangladesh by focusing on certain ratios over a period of five years. Five private commercial banks have been selected to undertake the research. Profitability measures - ROA and ROE are dependent variables and liquidity measures - Loan Deposit Ratio, Deposit Asset Ratio and Cash Deposit Ratio are selected as independent variables. The research carried out simple regression analysis to test the hypotheses. However, the null hypothesis is accepted in this study indicating that there is no significant relationship between liquidity and profitability.

Alshatti (2015) investigates the effect of the liquidity management on profitability in the Jordanian commercial banks during the time period (2005-2012). Thirteen banks have been chosen to express on the whole Jordanian commercial banks. The liquidity indicators are investment ratio, quick ratio, capital ratio, net credit facilities/ total assets and liquid assets ratio, while return on equity (ROE) and return on assets (ROA) were the proxies for profitability. Augmented Dickey Fuller (ADF) stationary test model was used to test for a unit root in a time series of the research variables and then testing hypothesis by using regression analysis. The empirical results show that a positive effect of the increase in the quick ratio and the investment ratio of the available funds on the profitability, while there is a negative effect of the capital ratio and the liquid assets ratio on the profitability of the Jordanian commercial banks.

Shrestha (2017) investigates the relationship between liquidity management and profitability and its impact on profitability of commercial banks in Nepal. The relation between the liquidity management 
and profitability is examined using Pearson correlation analyses. The effect of liquidity on profitability is analyzed using the regression analyses. The data has found to be covering period 2012-2016 of commercial banks in Nepal. The liquidity management represents the variables of the current reserve ratio (CRR), credit deposit ratio (CDR) and the profitability including return on equity (ROA). The result reveals that liquidity does not have its significant impact on profitability in Nepalese commercial banks.

\section{Methodology}

This research is purely based on secondary data of sample banks and has employed regression analysis to show the impact of liquidity variables (CR, LR and IR) on profitability (ROA) of the sample commercial banks. There are 27 commercial banks (government and private sector owned) operating in Nepal. All 27 licensed Nepalese commercial banks have been considered as the total population of this study. Out of them, only four commercial banks namely NABIL bank limited, Nepal Investment bank limited, Standard Chartered bank Nepal limited and Himalayan bank limited are taken as a sample. Four commercial banks consist of forty observations during fiscal year 2008/09 to 2017/18 with respect to ROA, CR, LR and IR.

\section{Statistical Model}

This research is evaluating the effect of liquidity on profitability by examining the financial data of sample commercial banks during the period from $2008 / 09$ to $2017 / 18$ by applying Linear Regression model as:

ROAit $=\alpha 0+\beta \mathrm{i} 1 \mathrm{IR}+\beta \mathrm{i} 2 \mathrm{LR}+\beta \mathrm{i} 3 \mathrm{CR}+$ eit

Where, dependent variable is: ROAit $=$ return on assets for the firm i during the period $t$, and independent variables are: IRit $=$ investment ratio for the firm $\mathrm{i}$ during the period $\mathrm{t}$, LRit $=$ liquid ratio for the firm i during the period $t, C$ Rit $=$ capital ratio for the firm i during the period $t, \alpha=$ constant, $\beta=$ regression coefficient and eit $=$ error term.

\section{Results}

\section{Descriptive statistics}

The descriptive statistics used in this study consists of mean, standard deviation, minimum and maximum values associated with variables under considerations. The descriptive statistics are summarized on table 1.

Table 1

\section{Descriptive statistics}

This table summarizes the descriptive statistics- minimum value, maximum value mean value and standard deviation of different variables used in this study during the period 2008/09 through 2017/18 associated with four sample banks. ROA is the variable used to measure the financial performance of commercial banks. The dependent variable used in the study ROA as Return on assets, the independent variables are; $C R$ as capital ratio, $I R$ as investment ratio and $L R$ as liquidity ratio.

\begin{tabular}{lccccc}
\hline Variables & $\mathrm{N}$ & Minimum & Maximum & Mean & Standard deviation \\
\hline ROA & 40 & 1.19 & 3.25 & 2.1860 & .47598 \\
CR & 40 & 4.68 & 16.57 & 8.7397 & 2.76988 \\
IR & 40 & 38.70 & 88.31 & 71.1835 & 11.67469 \\
LR & 40 & 10.98 & 37.52 & 22.2663 & 7.09914 \\
\hline
\end{tabular}

The figures in the table 1 show that the average return on assets (ROA) is 2.1860 percent with the minimum value of 1.19 percent and maximum value of 3.25 percent. Return on equity (ROE) ranges from minimum value of 14.31 percent to maximum value of 33.93 percent leading to the average of 24.3018 
percent. Similarly, the descriptive statistics for the independent variable shows that investment ratio has minimum value of 38.70 percent and maximum value of 88.31 percent leading to the mean of 71.1835 percent. The average liquidity ratio of the sample banks is noticed to be 22.2663 percent with a minimum value of 10.98 percent and maximum value of 37.52 percent. Capital ratio ranges from minimum value of 4.68 percent to maximum value of 16.57 percent with an average of 8.7397 percent.

\section{Correlation analysis}

Bivariate Pearson correlation coefficient analysis has been attempted to find the correlations between dependent and independent variables and the results are presented in table 2.

Table 2

Bivariate Pearson correlation coefficients for Return on Assets (ROA) and determinants of liquidity

This table reveals the Bivariate Pearson correlation coefficients of ROA. The independent variables are; IR as investment ratio, $L R$ as liquidity ratio, $C R$ as capital ratio.

\begin{tabular}{lcccc}
\hline Variables & ROA & CR & IR & LR \\
\hline ROA & 1 & .047 & -.271 & -.871 \\
CR & & 1 & -.206 & $.456^{*}$ \\
IR & & & 1 & $.361^{*}$ \\
LR & & & & 1 \\
\hline
\end{tabular}

* Correlation is significant at the 0.05 level (2-tailed).

Table 2 reveals that investment ratio is negatively related to return on assets which indicate that higher the investment ratio lower would be the return on assets of the banks. The liquidity ratio is negatively related with return on assets indicating that higher the liquidity ratio lower would be the bank performance measured by return on assets. Further, relationship between capital ratio and return on assets is found to be positive indicating higher the capital ratio of the bank higher would be the return on assets.

\section{Regression Analysis}

Regression analysis results are the statistical tools for the data analysis. The regression analysis has been conducted to examine whether or not the return on asset is affected by liquidity determinants of Nepalese commercial banks. The regression results of return on assets with different variables such as capital ratio, investment ratio and liquidity ratio are shown in table 3.

\section{Table 3}

Regression result of Return on Assets

This table shows regression analysis results of variables based on data of four commercial banks from the year 2008/09 to 2017/18. This table shows regression result as: $R O A i t=\alpha 0+\beta i 1 I R+\beta i 2 L R$ $+\beta i 3 C R+e i t$ in the form of simple and multiple regressions. The reported values are intercepts and slope coefficients of respective explanatory variables with $t$-statistics in parenthesis. Dependent variable is Return on Assets denoted as ROA and independent variables are; IRit as investment ratio, LRit as liquidity ratio and CRit as capital ratio.

\begin{tabular}{lccccccc}
\hline Specification & Intercept & IRit & CRit & LRit & R2 & F-value & P-value \\
\hline I & $2.985(6.511)$ & $-0.275(-1.766)$ & & & .076 & 3.119 & $.085^{*}$ \\
II & $3.914(6.844)$ & $-.399(-2.578)$ & & $-.382(-2.468)$ & .206 & 4.813 & $.014^{* *}$ \\
III & $3.805(6.623)$ & $-.017(-2.688)$ & $.206(1.237)$ & $-.486(-2.774)$ & .239 & 3.765 & $.019^{* *}$ \\
\hline
\end{tabular}

*Significant at 10 percent level.

**Significant at 5 percent level. 
The model III is acquired by the combination of IR, CR, and LR whereas R2 $=0.239$ shows that almost 23.9 percent change in dependent variable is because of change in independent variables and the rest of 76.1 percent is affected by market economy and other various factors. Similarly, whenever CR is added in model II, then R2 increases and the positive coefficient of CR indicates that there is positive relationship between ROA and CR. The P-value indicates that the model is significant at five percent level.

However, beta coefficients for investment ratio and liquidity ratio are negative with return on assets indicating increased investment ratio and liquidity ratio decrease the return on assets of the bank. Further, beta coefficient is positive for capital ratio with return on assets.

\section{Conclusion}

Results revealed that return on assets is positively related to capital ratio. This indicates that higher the capital ratio higher would be the return on assets. Similarly, correlation between investment ratio and liquidity ratio to ROA is found to be negative indicating higher the investment ratio and liquidity ratio lower would be the return on assets and vice versa.

Beta coefficient is positive for capital ratio with bank performance which indicates that increased capital ratio increases the bank performance. However, beta coefficient for liquidity ratio and investment ratio is negative with return on assets indicating increased liquidity ratio and investment ratio decrease the return on assets of the bank, but this relation is not significant at five percent level. This study concludes that liquidity status of the bank plays important role in banking performance in case of Nepalese commercial banks. The study suggests that banks willing to increase bank performance should increase capital ratio and control investment ratio and liquidity ratio.

\section{References}

Abdullah, M. N. \& Jahan, N. (2014). The impact of liquidity on profitability in banking sector of Bangladesh: A case of Chittangong Stock Exchange. International Journal of Economics and Business Review, 2(10), 17-22.

Alshatti, A. S. (2015). The effect of liquidity management on profitability in the Jordanian commercial banks. International Journal of Business and Management, 10(1), 62-72.

Amengor, E. C. (2010). Importance of liquidity and capital adequacy to commercial banks. A Paper Presented at Induction Ceremony of ACCE, UCC Campus.

Khan, R. A. \& Ali, M. (2016). Impact of Liquidity on Profitability of Commercial Banks in Pakistan: An Analysis on Banking Sector in Pakistan . Global Journal of Management and Business Research, 16 (1), 53-59.

Malik, M. S., Awis, M. \& Khursheed, A. (2016). Impact of liquidity on profitability: A comprehensive case of Pakistan's private banking sector. International Journal of Economics and Finance, 8(3), 69-74.

Nahum, N.\&Amarjit, S. G. (2013).The impact of corporate governance on working capital management efficiency of American manufacturing firms. Emerald Publishing Ltd.

Shrestha, B. (2018). Liquidity management and profitability of commercial banks in Nepal. Proceedings of ARSSS International Conference, 27th May, 2018, New Delhi, India.

Sunny, O. I. (2013). The impact of liquidity management on the profitability of banks in Nigeria. Journal of Finance and Bank Management, 1(1), 37-48. 
Issue 1 May/June 2020 - 